\title{
Statistical Analysis of Structured Data on the Consumption of Meat and Meat Products in Russia
}

\author{
Zolotareva O.A. \\ Department of Statistics \\ G.V. Plekhanov Russian University of Economics \\ Moscow, Russia \\ Makhova.OA@rea.ru
}

\author{
Davletshina L.A. \\ Department of Statistics \\ G.V. Plekhanov Russian University of Economics \\ Moscow, Russia \\ Davletshina.la@rea.ru
}

\author{
Antipova D.D. \\ Department of Statistics \\ G.V. Plekhanov Russian University of Economics \\ Moscow, Russia \\ Antipova.DD@rea.ru
}

\begin{abstract}
The article addresses the issues of food security and import substitution. It examined the dynamics of production and per capita meat consumption in the Russian Federation. Structural changes in the production of basic livestock products for farms of all categories are considered. Based on the analysis, it is concluded that a well-thought-out state policy aimed at supporting domestic producers not only avoided the food crisis, but also contributed to the intensive development of the meat and meat products market. A number of problems were also identified and recommendations formulated, defined by digital transformation, which are rightly associated with the new industrialization, which in turn implies a set of measures to upgrade technologies and organize production, including meat production and processing.
\end{abstract}

Keywords-food security; food market; meat and meat products market; animal husbandry; meat consumption.

\section{INTRODUCTION}

Providing yourself and your loved ones with a set of goods and services for a decent and comfortable life is one of the key aspects of the quality life of any person. As a confirmation of this thesis, we can cite the generally accepted theory of the human needs hierarchy, proposed by A. Maslow, according to which the primary needs are physiological, including the food requirements [1]. Thus, the main tasks of the state should include providing the population with basic foodstuffs necessary for human life [2].

According to the Recommendations on rational food consumption standards that meet modern requirements for a healthy diet (hereinafter Recommendations), meat and meat products per person per year are recommended to be consumed in the amount of $73 \mathrm{~kg}$ [3]. Meat and meat products as a whole contain complete proteins that are closest in amino acid composition to human proteins, a significant amount of fats, carbohydrates, minerals and vitamins that determine their nutritional value.

In the structure of the food market, the market for meat and meat products occupies key positions. Being an economic mechanism of relations between business entities involved in the process from production to distribution of products, it also touches on the issues of providing the population with these vital food products and the food security of the state [4].

The needs of residents in meat and meat products to a significant extent should be provided by their own products and raw materials by increasing production volumes, reducing the existing regional differentiation and be oriented towards developing the most efficient livestock industries. At the same time, one should not lose sight of the fact that the production of meat and meat products is considered a more complex and diverse field of activity in the agricultural sector. The key aspects influencing are: natural and biological conditions, provision of animal feed, national priority in the consumption of meat, modern changes in technology and organization of production [5].

\section{LITERATURE REVIEW}

The works of foreign scientists are devoted to the consideration of the market as an economic category, the study of basic market laws, the study of supply and demand: S. Brue, T. Veblen, J. Keynes, F. Kotler, C. McConnell, A. Marshall, W. Petty, M. Porter, D. Ricardo, A. Simt, I. Schumpert and others.

The work is dedicated to improving the functioning of the domestic agricultural complex: M.N. Alekseeva, A.I. Altuhovao. V. Bakanach, D.F. Vermel, A.S. Gureeva, M.S. Ilyina, V.P. Mozhina, V.Ya. Uzuna, O.N. Fetyukhina and 
others. They examined the problems of the agricultural sector of the country, proposed solutions to them and characterized the directions of further development of the industry. At the same time, the authors noted the imperfection of the functioning mechanism of the Russian meat market, both at the regional level, at the teak level and at the level of the country as a whole, the need for its comprehensive reform and increased attention to it from the state [6].

\section{RESEARCH METHODOLOGY}

In order to obtain a complete, reliable picture of the current state of the domestic food market for meat and meat products and assess the effectiveness of the implementation of policy measures aimed at achieving food security, a comprehensive statistical analysis based on the use of quantitative indicators system is necessary. In this context, in the work, the data of official statistical information provided by the Federal State Statistics Service were analyzed on the basis of economic and statistical methods for the analysis of phenomena and processes. Proper application of the methodology allowed us to qualitatively characterize the real state of affairs in the development of the food market for meat and meat products in the country, as well as to develop a number of recommendations aimed at increasing the volume of meat products production [7].

\section{RESUlTS}

In 2012, the Government of the Russian Federation adopted the Strategy for the Development of the Food and Processing Industry of the Russian Federation until 2020 (hereinafter referred to as the Strategy) [8]. When developing the strategy, the current federal documents related to the socio-economic development of the country and its food security were taken into account, as well as the norms of healthy nutrition and rational consumption of food products were taken into account [9].

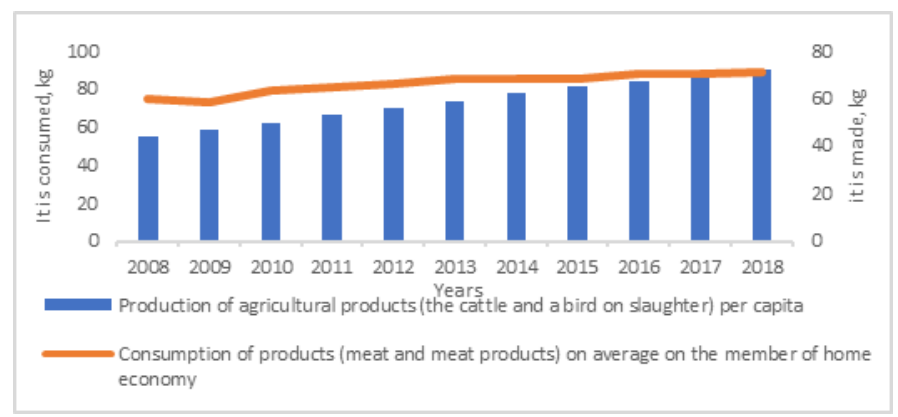

Fig. 1. Dynamics of production and per capita meat consumption in Russia, 2008-2018

The post-perestroika years for Russia were marked by the decline of most industries, including agriculture. As a result, the country became dependent on imports for key products, where meat and meat products were no exception. The imposition of sanctions against Russia, the announcement of the food embargo and the policy of import substitution were reflected in the increase in per capita agricultural production. However, with the increase in the average consumption of products per household member (meat and meat products), the existing gap with the volume of domestic production by 2018 has not been eliminated.

Therefore, the adoption of the Strategy, the purpose of which is that the food and processing industry should be able to provide a guaranteed and sustainable supply of safe and quality food to the country's population, is very timely and relevant. A guarantee of achieving this goal should be the stability of food and raw materials domestic sources, as well as the availability of necessary reserve funds.

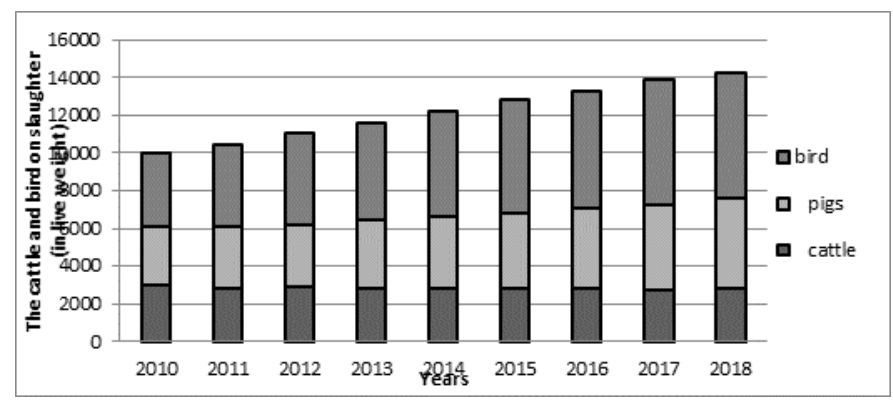

Fig. 2. Production of basic livestock products in the Russian Federation for 2010-2018, farms of all categories; thousand tons

As the level population of the country well-being grows, the volume of consumer demand for meat and meat products increases. In recent years, the country's physical sales of meat of all kinds in retail trade have increased annually by an average of $5.0 \%$ or an average of $2.5 \mathrm{~kg}$ annually. Moreover, for the period from 2010 to 2018 a transformation of the production structure of the main livestock products was recorded - an increase in the production of pork (annual growth by an average of 5.6\%) and poultry (annual growth by an average of $5.6 \%$ ) with a simultaneous decrease in the share of cattle (annual decline by an average of $1,0 \%$ ). It is worth noting that the level of meat and meat products consumption by the population of Russia since 2010 has been above the recommended rational norm (annual growth by an average of $2.6 \%$ ), with very significant structural distortions by type of meat [10].

All livestock and poultry farms of the Russian Federation can be divided into three categories: agricultural enterprises (commodity farms), individual (peasant) farms, and rural households (small farms that produce products for their own consumption, and where there are often others that are not related to agriculture, sources of income) [11].

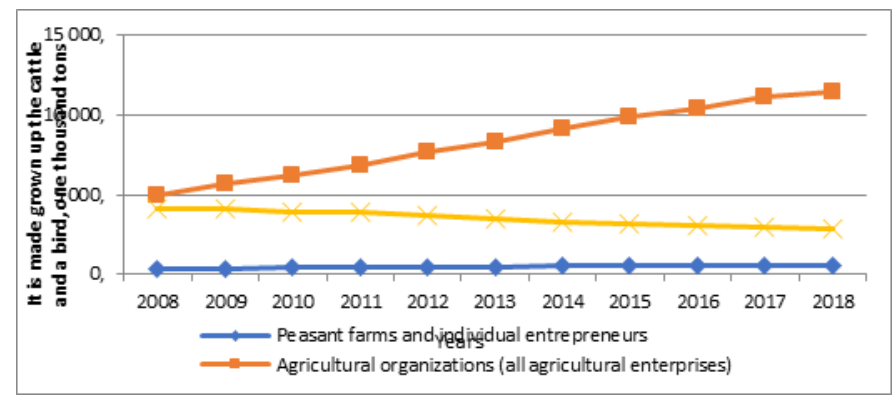

Fig. 3. Produced (grown) livestock and poultry (in live weight) for the year in Russia for 2008-2018, thousand tons 
According to the All-Russian Research Institute of Beef The recent increase in livestock was accompanied by a redistribution of roles between these categories. Due to the great opportunities for access to state financing, economies of scale. It is taking a step to consolidate the industry, the loss of its former importance by traditional meat markets and the strengthening of modern retail chains, meat producers have significantly strengthened their position. Large livestock enterprises that previously carried out only slaughter and butchering, begin to develop the production of finished meat products. Retail chains require a stable supply of meat, consistent quality and compliance with food safety standards. Many support programs stipulate that a holding be officially registered as an enterprise. Otherwise, it cannot receive either state support or a subsidy to pay interest on loans [12].

Along with economic reasons, a number of social and demographic factors contribute to the reduction of livestock and poultry farming in rural households, including the aging of the rural population and the migration of youth to urban areas [13].

The President of the Russian Federation, within the framework of the Strategy, set the task in the coming years to fully ensure the country's independence in all major types of food and become the world's largest food supplier. In this regard, by 2020 , it is necessary to replace the volume of imported products in the amount of 1.3 trillion rubles, including livestock and poultry meat - about 10 million tons, which will reduce the supply of imported products by 67.8 percent [14].

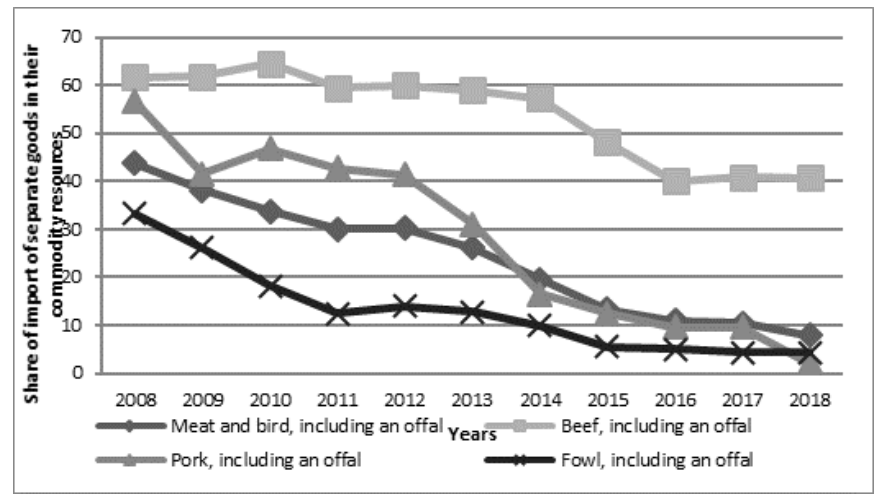

Fig. 4. The share of individual goods imports in their commodity resources for 2008-2018 in Russia, \%

Over the past decade, the volume of meat and meat products imports in their commodity resources has significantly decreased. The most notable changes occurred in pork meat, including offal, with an average annual decrease of $27.7 \%$. The types of meat products that are next in intensity of the changes that have taken place are poultry meat, including offal (a decrease of $18.5 \%$ ), as well as meat and poultry, including offal $(15.7 \%)$. Only sausage products had an annual average increase of $3.15 \%$. Over the entire period, despite an annual decrease of $4.1 \%$ on average, the highest values are characteristic for the category "Beef, including offal". A similar situation could have arisen for a number of reasons: a higher cost and a longer time for raising cattle, and a difficult production base [10].
Cattle Breeding, only five percent of Russian beef is obtained from meat and meat and dairy breeds. If we talk about the beef market, quality meat has only become available recently, with the start of imports from the United States, Brazil, Australia, the EU and Argentina. Most likely, the further development of beef production will be focused on a niche market, where the dominant demand is from high-income residents of large cities [10].

The state of the industry production base requires solving a number of problems aimed at innovative and technological updating of production and the introduction of investment programs in the field of processing raw meat [8].

A promising direction for the development of the meat industry may be an increase in the depth of processing of raw meat, including an increase in the production of food, medical, technical and feed products from the blood, as well as the production of semi-finished meat products that are in high demand among the population [15].

Despite the development of poultry farming in Russia, the share of poultry in the total production of livestock and poultry for slaughter in slaughter weight in agricultural organizations is about 58 percent. Most of the equipment is morally and physically obsolete (with the exception of newly commissioned facilities) [16].

Providing the population with meat and meat products and the guarantor of food security of the state are import substitution due to an increase in the production of Russian marketable meat on the basis of modern complexes creation for slaughtering livestock, development of infrastructure and logistic support, which will expand the possibilities (in terms of) storage of raw materials and products, reduce the number waste and improve the environmental situation in the industry as a whole [17].

\section{CONCLUSIONS}

The article examined structured data on the consumption of meat and meat products in Russia. The study identified "pain points" of the industry: firstly, the impossibility of satisfying the needs of the country's population for meat and meat products with its own resources, secondly, structural differences in the types of livestock (poultry) and poultry produced, and thirdly, a decrease in the number of family farms, an increase in the number of agricultural enterprises.

Despite the growth in meat production, the use of the average annual capacity of organizations is still low and in 2014 the following types of products were produced: meat and offal - 67.1 percent; sausages - 57.1 percent; canned meat 53.5 percent. The production of meat and meat products is closely related to the development of livestock. Constraining factors in the development of the industry are the limited raw material base and the lack of capacity for primary processing of cattle.

It is necessary to provide for the construction, reconstruction (modernization) of production facilities for slaughter and primary processing of livestock within the 
[6] Puzakov A.V. The Russian market of meat and meat products: essence, development factors, features of statistical research // Economics and Entrepreneurship. 2015. No. 2 (55). S. 967-972.

framework of a single production cycle that includes the main stages of the production chain (from the acceptance of domestic slaughtered animals to cutting and storage of meat and offal, processing of all slaughter products, including all types of basic and by-products).

The picture that has developed on the market of meat and meat products in Russia, taking into account the support measures described in the Strategy, will help to solve the following problems:

- increase in the capacity of organizations for the primary processing of livestock due to the construction of modern facilities;

- an increase in the collection and processing of secondary raw materials for the development of various types of products;

- re-equipment of processing workshops with modern equipment and technologies, creation of new industries.

\section{Acknowledgment}

The authors are grateful for the research support of the Russian Foundation for Basic Research (RFBR) (within the framework of the project "Study of the potential of domestic manufacturers to ensure import substitution in the consumer market using Big Data technologies", grant No. 17-02-00718OGN).

\section{References}

[1] "Motivation and Personality" by Abraham Maslow, 1954

[2] Bashina O.E., Tsaregorodtsev Yu.N., Davletshina L.A. et al. Research on the development of the production of bread and bakery products to ensure import substitution in the consumer market of Russia, Moscow: Moscow Humanitarian University (Moscow), 2018, p. 128, ISBN: 978 5-907017-80-1

[3] Order of the Ministry of Health of the Russian Federation of August 19 2016 No. 614 "On approval of the Recommendations on rational food consumption standards that meet modern requirements for healthy eating https://www.garant.ru/products/ipo/prime/doc/71385784/ \# 0

[4] Darda E.S. The development of livestock in the Russian Federation: an assessment of trends and development prospects // In the collection: Russia: trends and development prospects Yearbook. Executive Editor V.I. Gerasimov. Moscow, 2017.S. 481-485.

[5] Pershina T.A., Davletshina L.A. Statistical analysis of a generalized integral indicator of the socio-economic situation of the constituent entities of the Russian Federation // University Bulletin, Publisher: State University of Management (Moscow), No. 5, 2018, pp. 11-19, ISSN: $1816-4277$
[7] Davletshina L.A. Problems of data collection and analysis in the Russian economy // Innovative development of the Russian economy / IX International Scientific and Practical Conference. Ministry of Education and Science of the Russian Federation; Federation Russian Economic University named after G.V. Plekhanov; Russian Humanitarian Science Foundation. 2016, p. 99-101

[8] The development strategy of the food and processing industry of the Russian Federation for the period until 2020 http://static.government.ru/media/files/65bZISIOP6bA0VSJ67GnnpKIh hoHhxgP.pdf

[9] Olga Bashina, Yury Tsaregorodtsev, Vladimir Nikolenko, Leysan Davletshina, Artem Fedoseev, Environmental issues and the state program of agriculture development in the Russian Federation / VI International Multidisciplinary Scientific Conference on SOCIAL Sciences \& Arts, SGEM 2019, 4 AUG-2 SEPT , 2019 ISSN 2367-5659 (in press)

[10] Review of the meat industry / analytical review / Prepared as part of the FAO-EBRD collaboration program. Food and Agriculture Organization of the United Nations, Rome, 2014

[11] Darda E.S., Agriculture as a factor of food security // Materials of the 3rd International Multidisciplinary Scientific Conference on Social Science and Arts. Pudlished by STEF92 Technology Ltd., 51 "Alexander Malinov" Blvd., 1712 Sofia, Bulgaria

[12] Natalia Sadovnikova, Ekaterina Darda, Svetlana Babich, Sergey Golodov, Edward Ilin Features of economicmathematical models building of development of the Russian federation agroindustrial complex // Materials of the 4rd International Multidisciplinary Scientific Conference on Social Science and Arts. Pudlished by STEF92 Technology Ltd., 51 "Alexander Malinov" Blvd., 1712 Sofia, Bulgaria Total print: 5000 book 4

[13] Davletshina L.A. Analysis of the development of the regions of the Russian Federation according to the main indicators of the sociodemographic situation // Statistical analysis of the socio-economic development of the constituent entities of the Russian Federation / Materials of the 3rd International Correspondence Scientific and Practical Conference. 2017 Publisher: Bryansk State Academy of Engineering and Technology (Bryansk), p. 78-82

[14] Simonova M.D. Problems of measuring international trade in a globalized world. // Questions of statistics. - 2013. - No. 1. - with. 69-74.

[15] Karmanov M.V. Russian statistics in the context of international sanctions // Questions of statistics / Publisher: Information and Publishing Center "Statistics of Russia", No. 1, 2015, p. 77-80

[16] Sibirskaya EV, Oveshnikova LV, Makhova O. A. Statistical analysis of entrepreneurial activity // Questions of statistics / Publisher: Information and Publishing Center "Statistics of Russia", Volume: 25, No. 10, 2018 p. 47-60

[17] Karmanov MV, Makhova OA Garbage as a problem of civilization: features and evaluation // Bulletin of the Department of Statistics of the Russian Economic University named after G.V. Plekhanova / Statistical studies of the socio-economic development of Russia and prospects for sustainable growth: materials and reports. Under the total. ed. ON. Sadovnikova. S. 178-181, 2018 